FELIKS KIRYK

Uniwersytet Pedagogiczny w Krakowie

\title{
MAŁOPOLSKIE MIASTA PRYWATNE W XIII-XVI WIEKU
}

Zarys treści: Zagadnienie powstania i rozwoju miast prywatnych w Małopolsce nie zostało dotąd do końca rozpoznane, także z powodu znacznych luk źródłowych. Wiadomo jednak, że powstały one później niż miasta królewskie, w większości w XV-XVI w. i były z reguły ośrodkami mniejszymi, ale przeważały liczebnie, stanowiąc aż $2 / 3$ wszystkich miast. W artykule przedstawiono dane statystyczne dotyczace chronologii powstawania miast Małopolski w jej historycznych granicach. Zwrócono uwagę na zróżnicowane funkcje, wyróżniając ośrodki górnicze, skupione głównie w regionie Gór Świętokrzyskich, miasta produkcyjne i handlowe. Wymieniona kategoryzacja została udokumentowana licznymi przykładami.

The content outline: The issue of the foundation and development of private towns in Lesser Poland has not yet been fully analysed, partially due to significant gaps in source materials. It is known, however, that such towns were created later than royal towns, mostly in the $15^{\text {th }}-16^{\text {th }}$ century and were usually smaller in size but more widespread, constituting $2 / 3$ of all towns. The paper presents statistical data concerning the chronology of the creation of towns within the historical borders of Lesser Poland. Diverse functions of urban centres are indicated in the paper, with emphasis placed on mining towns, located primarily in the area of Świętokrzyskie Mountains, production towns and trade towns. This classification is documented with numerous examples.

Słowa kluczowe: Małopolska, miasta, średniowiecze, lokacje, urbanizacja

Keywords: Lesser Poland, towns, the Middle Ages, foundations, urbanisation

Miasta prywatne pojawiły się $\mathrm{w}$ Małopolsce $\mathrm{u}$ progu urbanizacji kraju na etapie struktur gospodarczych i społecznych o charakterze miejskim, kolonii przybyłych na ziemie polskie „gości” oraz ludzi utrzymujących się z zajęć pozarolniczych, nie tworząc jeszcze wyodrębnionych terytorialnie i zorganizowanych pod względem ustrojowym, 
samorządowych gmin miejskich. Stanowiły zaledwie początki miast na tzw. prawie polskim. Niosła je niebawem urbanizacja kraju na prawie niemieckim, jedna z największych i najważniejszych reform gospodarczych średniowiecza, o wielorakich skutkach społecznych, ustrojowych i kulturalnych ${ }^{1}$.

W wielkim zespole miast lokacyjnych ${ }^{2}$, obok miast monarszych, lokowanych głównie w stolicach prowincji oraz ośrodkach władzy kasztelańskiej, znalazły się również miasta prywatne, zagadnienie do tej pory słabo zbadane, chociaż w dziejach urbanizacji kraju ważne, niemal kluczowe. Dotyczy bowiem 2/3 wszystkich, powstałych od głębokiego średniowiecza po ostatnie dekady XVI stulecia, miast małopolskich ${ }^{3}$. Należy do obszernych i trudnych zadań naukowych, nie tylko dlatego, że skupia fakty i wydarzenia długiego trwania, lecz także z tego

${ }^{1}$ Zob. K. Buczek, Targi i miasta na prawie polskim, Wrocław 1964, s. 92-112; Miasta doby feudalnej $w$ Europie Środkowo-Wschodniej. Przemiany społeczne a uktady przestrzenne, red. A. Gieysztor, T. Rosłanowski, Warszawa 1976, Warszawa 1976, passim; Sieć miejska na ziemiach polskich $w$ XIII-XVII w., KHKM, t. 28, 1980, nr 3 (teksty pióra K. Modzelewskiego, H. Samsonowicza, J. Wiesiołowskiego, J. Wyrozumskiego), s. 325-372.

${ }^{2}$ Odnoszą się do nich całe dziesiątki opracowań dawniejszych i z ostatniego siedemdziesięciolecia. Przybywa ich zreszta stale. Zbiera je w większości książka: M. Bogucka, H. Samsonowicz, Dzieje miast i mieszczaństwa w Polsce przedrozbiorowej, Wrocław 1986, s. 589-647, a przede wszystkim liczne monografie poszczególnych ośrodków miejskich, m.in.: Krakowa, Nowego Sącza, Sandomierza, Lublina, Tarnowa, Mielca, Częstochowy, Sławkowa, Siewierza i wielu innych; por. też J. Motylewicz, Miasta ziemi przemyskiej $i$ sanockiej $w$ drugiej połowie XVII $i$ XVIII w., Przemyśl 1993, s. 293-303.

${ }^{3}$ Zostały one opracowane przez mnie w powstałym na przełomie lat 60 . i 70 . minionego stulecia, 60-arkuszowym opracowaniu pt. „Rozwój urbanizacji Małopolski XIII-XVI wieku”, które stało się w 1974 r. podstawą habilitacji. Mimo pochlebnych ocen nie zostało ono - z racji ogromnej objętości, ciagłego braku papieru oraz środków finansowych na wydawnictwa naukowe - skierowane do druku. Publikowałem więc przez wiele lat fragmenty tego obszernego dzieła, do których - zważając na rozbudowaną dokumentację źródłową i ogromną liczbę opracowań, artykułów, tabel, itp., a także niemożność ich uwzględnienia w niniejszym szkicu - odsyłam czytelnika. Poza tekstem oryginalnym w maszynopisie (dostępnym w archiwum Uniwersytetu Pedagogicznego w Krakowie) są to artykuły i wydawnictwa książkowe: $Z$ badań nad urbanizacja Lubelszczyzny $w$ dobie jagiellońskiej, „Rocznik Naukowo-Dydaktyczny WSP w Krakowie" 43, 1972, s. 93-167; Rozwój urbanizacji Małopolski XIII-XVI w. Województwo krakowskie (powiaty południowe), Kraków 1985; Urbanizacja Małopolski. Województwo sandomierskie XIII-XVI wiek, Kielce 1994; Z dziejów urbanizacji Wyżyny Krakowsko-Częstochowskiej w średniowieczu, w: Zróżnicowanie i przemiany środowiska przyrodniczo-kulturowego Wyżyny Krakowsko-Częstochowskiej, t. 2: Kultura, Ojców 2004, s. 25-40; Miasta ziemi sqdeckiej w XIII-XVI wieku, „Rocznik Sądecki” 35, 2007, s. 25-116. 
powodu, że jest ich pokaźna ilość i stanowią specyficzny, odrębny i właściwy sobie problem badawczy, nienadający się do uogólnień i łatwego opisu sumarycznego ${ }^{4}$.

$\mathrm{Na}$ drodze do ich rozpoznania stoi przede wszystkim bariera źródłowa. Dotrwały do naszych czasów bowiem zaledwie szczątki materiałów źródłowych, nazbyt skape, aby można na ich podstawie zbadać dostatecznie losy poszczególnych ośrodków miejskich, co odnosi się nie tylko do wieków odległych, jak XIII i XIV stulecie. Brakuje ich również $\mathrm{w}$ odniesieniu do stuleci kolejnych. To, co pozostało w tej mierze jest istotnie skape, nierównomierne i fragmentaryczne. Nie może być przy tym mowy o zachowaniu ciagłości informacji źródłowych. Sa one lakoniczne i rwane. Nierzadko bywa i tak, że o niektórych miastach wiadomo sporo w okresie XIII czy XIV w., po czym brakuje o nich informacji przez szereg dziesięcioleci, a nawet stulecie czy półtora wieku. Wielka szkoda, gdyż owe różne defekty materiałowe dotyczą zwykle małych ośrodków miejskich, przeważających w zespołach miast prywatnych, o których byłoby warto posunać naprzód dotychczasowy stan wiedzy.

${ }^{4}$ Pobieżna nawet analiza odnoszącego się do miast prywatnych materiału źródłowego umacnia pogląd, że narodziny każdego z nich - niezależnie od wielu cech wspólnych - było rezultatem rozwoju indywidualnego. Jemu dopiero możemy przypisać bowiem powstanie bogactwa różnorodnych, właściwych mu form specyficznych, odróżniających go od sąsiednich ośrodków miejskich, rysów powiązanych jednakże chronologicznie z innymi charakteryzującymi miasto czynnikami miastotwórczymi. Także ustalenie chronologii podstawowych faktów w dziejach każdego z nich należy do podstawowych i ważnych, chociaż niełatwych zabiegów badawczych. Jesteśmy przy tym skłonni dopatrywać się bowiem znacznej różnicy między genezą miasta prywatnego w XIII i XIV stuleciu a miasta $\mathrm{w}$ dobie ich erupcji, zwłaszcza w drugiej połowie XV i XVI w. Dają o sobie znać różne problemy terminologiczne. Trudno nie zauważyć różnic własnościowych między dawnymi, prywatnymi ośrodkami miejskimi. Nie da się bez zastanowienia przejść nad przyporządkowaniem do prywatnych ośrodków miejskich miast należących do określonego możnowładcy czy też zamożniejszego szlachcica oraz miasta wchodzącego w skład włości instytucji kościelnych, jak zakony (czy raczej klasztory) oraz biskupstwa, kapituły kolegiackie i probostwa, stanowiącego w istocie własność zbiorowa, określona też nierzadko jako majętność martwej ręki. Nie jest przecież prawda, że ową prywatność majątkową traktujemy tak samo, gdy rozpatrujemy losy miasta należącego do właściciela w postaci konkretnego człowieka i również wtedy, gdy zajmujemy się miastem należącym do właściciela o charakterze zbiorowym, a więc kościoła czy klasztoru. Nie można więc rozpatrywać, że zakres pojęcia prywatności się rozmywa, staje się dosyć niejasny. Warto o tym pamiętać. Zaznaczymy tu również, że znamy inna, związaną z problematyką miejska, własnością gruntowa podlegająca samorządowi municypalnemu, stanowiąca zagadnienie odrębne, którym tu się nie zajmujemy. Pozostaje jeszcze problem związku miast prywatnych z polityka, a konkretnie kurczeniem się domeny królewskiej na rzecz majętności prywatnych. A przecież nie tylko gospodarcze i polityczne znaczenie tych miast jest istotne. Pozostaje ważny ich wpływ na życie społeczne i kulturalne. 
W niewielkim tylko stopniu udało się owe braki zrekompensować systematyczną i rzetelną kwerendą źródłowa, doceniając wartość każdego niemal przekazu informacyjnego. Objęła ona źródła rękopiśmienne i drukowane $\mathrm{z}$ archiwów i bibliotek naukowych krajowych oraz zagranicznych (Słowacja, Ukraina, Węgry) i pozwoliła uświadomić sobie, jak wiele świadectw źródłowych o dawnych miastach i miasteczkach przepadło bezpowrotnie podczas ciagle powtarzających się w nich pożarów i innych klęsk żywiołowych oraz działań wojennych ${ }^{5}$. Trzeba było pogodzić się więc z faktem owych nieodwracalnych strat źródłowych i zdecydować się na zebranie wszystkiego, co w tej mierze dotąd pozostało. W wyniku wieloletnich poszukiwań archiwalnych udało się jeszcze zebrać pokaźny w sumie materiał źródłowy o najdawniejszych miastach małopolskich, chociaż niewolny od dotkliwych luk, a nawet przypadków całkowitego niemal braku nośników informacyjnych. Starałem się wykorzystać także, gdzie było to możliwe, wyniki badań archeologicznych, co przy nakreślonym deficycie źródeł pisanych okazało się niejednokrotnie cenne i pożądane ${ }^{6}$.

Zagadnienie kolejne dotyczyło oznaczenia czasu pojawienia się na widowni dziejowej poszczególnych miast prywatnych. Towarzyszyła temu znacząca nierównomierność i potrzeba wniesienia uwag

${ }_{5}$ Wspomnimy tu tylko straty archiwalne spowodowane przez I, a zwłaszcza II wojnę światowa, podczas których uległy zatracie liczne archiwalia masowe, lokalne i regionalne, w tym szczególnie cenne księgi sądowe grodu sandomierskiego i księgi miejskie wielu miast ziemi sandomierskiej.

${ }^{6}$ Do rozważań wstępnych zgłaszamy jeszcze uwagę, że terytorium naszych dociekań stanowi Małopolska historyczna, po przezwyciężeniu rozbicia dzielnicowego, podstawowy (obok Wielkopolski) składnik terytorialny państwa piastowskiego. Obejmowała bowiem dzielnicę krakowsko-sandomierska, od XIV stulecia woj. krakowskie i sandomierskie, a od połowy XV w. woj. krakowskie (z pow. śląskim i księstwem siewierskim) i sandomierskie oraz (od 1474 r.) lubelskie z ziemia łukowska. W sensie geograficznym były to ziemie górnego i środkowego biegu rzeki Wisły od Oświęcimia do Zawichostu, następnie od Zawichostu do Sieciechowa i prawobrzeżnych dopływów wiślanych (Soła, Raba, Dunajec, Wisłoka, San, Wieprz) oraz dopływów lewobrzeżnych (Szreniawa, Nida, Pilica, Radomka). Teren bardzo rozległy, przykryty przed wiekami szata leśna, miejscami nawet o charakterze puszczańskim, zróżnicowany pod względem glebowym i klimatycznym, niejednakowo przyciagającym osadnika. Najstarsze osadnictwo zmierzało zatem lewym brzegiem Wisły ku wschodowi i północy od Krakowa i Sandomierza, obejmując żyzne obszary Doliny Nadwiślańskiej, a także Wyżyny Sandomierskiej oraz wcześnie zasiedlone enklawy - kielecko-tarczeńska, małogosko-mstowską i żarnowsko-skrzyńską. Na wschodzie objęło biegiem Radomki okolice grodu w Radomiu i na południu ekumenę staroiłżańska, a na północy sieciechowska, przesuwając się za Wisłę ku grodowi w Łukowie. Tu skręcając ku południowi, wkraczało na Wyżynę Lubelską i sasiadujący z nią wyraźny pas osadniczy między Wieprzem a Bugiem. Od prawieku była to kraina usiana grodziskami, niektórymi jeszcze z czasów wiślańskich. Nie wszystkie się utrzymały. Wyznaczyły jednak strefy najdawniejszego osadnictwa. 
w zakresie periodyzacji zabiegów lokacyjnych. Wynikały one stąd, że miasta kościelne i zakonne, tak jak miasta monarsze (królewskie), pojawiły się znacznie wcześniej niż ośrodki możnowładcze i szlacheckie. Te pierwsze w XIII i XIV, a drugie w XV i XVI stuleciu. Oznacza to bowiem, że oblicze miast prywatnych kształtowało się w dwu stosunkowo odmiennych etapach, mianowicie gospodarki przeważnie towarowo-pieniężnej oraz głównie folwarczno-pańszczyźnianej. Granica czasowa tych okresów nie jest oczywiście ścisła, niemniej rysują się one w historii miast prywatnych stosunkowo wyraźnie.

Do ujęć podręcznikowych należy wiedza, że w systemie feudalnym ziemia stanowiła podstawę egzystencji społecznej, źródło codziennego utrzymania i wszelkiego rodzaju bogactwa. Przyjmuje się, że pełnym jej właścicielem był pierwotnie monarcha, zanim droga rekompensaty za usługi urzędnicze i militarne, a także religijne uruchomiona została polityka uszczuplania własności monarszej wskutek feudalnych nadań. Wytworzyła się, obok własności królewskiej (monarszej), własność prywatna, należąca do duchowieństwa świeckiego, klasztorów oraz do zasłużonych wobec władzy reprezentantów stanu rycerskiego. Odegrały one ważną rolę również w urbanizacji. Dzieje owych nadań stanowia ciagle interesujący aspekt historii Polski okresu piastowskiego i jagiellońskiego, odbijający się żywo na stosunkach politycznych społecznych, gospodarczych i kulturalnych kraju. Na ich podstawie łatwiej rozpatrywać czynniki wzrostu oraz przyczyny zahamowania w rozwoju ekonomicznym monarchii. Był to $\mathrm{z}$ jednej strony proces formowania stanu duchownego i rycerskiego, w tym możnowładztwa świeckiego i kościelnego, z drugiej zaś osłabiania gospodarczego państwa i powolnego obniżania znaczenia władzy centralnej. Owe nadania nie ustały w czasach andegaweńskich i jagiellońskich ${ }^{7}$. Objęły wcześniej duchowieństwo świeckie i zakonne oraz urzędników państwowych szczebla centralnego, nasilając się $\mathrm{w}$ dobie rozbicia dzielnicowego i procesów zjednoczeniowych w XIII i XIV w. ${ }^{8}$ Rujnujący domenę królewską etap przypadł na koniec monarchii Jagiełły, a przede wszystkim na panowanie jego syna, Władysława Warneńczyka9 .

${ }^{7}$ Por. S. Gawęda, Możnowładztwo małopolskie $w$ XIV $i$ pierwszej połowie XV wieku, Kraków 1966, s. 17, 25-125; J. Kurtyka, Tęczyńscy. Studium z dziejów polskiej elity możnowładczej $w$ średniowieczu, Kraków 1997, s. 106-132, 425-463; tenże, Latyfundium tęczyńskie. Dobra i wtaściciele (XIV-XVII wiek), Kraków 1999, s. 35-102.

8 J. Baszkiewicz, Powstanie zjednoczonego państwa polskiego na przełomie XIII i XIV wieku, Warszawa 1954, s. 285-360.

9 Zob. ZDM, t. 8, wyd. I. Sułkowska-Kuraś, S. Kuraś, Wrocław 1975, nr 2175-2497; S. Kwiatkowski, Ostatnie lata Warneńczyka, „Przewodnik Naukowy i Literacki” 11, 1883, s. 74, 136-137. 
Wynika więc z tego, że nadania królewszczyzn na rzecz Kościoła i klasztorów nastapiły w swojej masie w XI-XIV stuleciu, przyczyniając się do rozwoju miast kościelnych i klasztornych, nadania późniejsze natomiast (XV-XVI w.) dają się powiązać dopiero z rozwojem miast możnowładczych i szlacheckich.

Podmiotami miastotwórczymi w historii urbanizacji kraju byli-poza monarchą i instytucjami kościelnymi oraz klasztornymi - pozostali posiadacze ziemscy, właściciele zasiedlonych wsi, nierzadko dziedzice zamków i innego rodzaju warownych osad, ludzie zamożni i wpływowi. W ich rękach spoczywała inicjatywa lokacyjna i łatwość dostępu do władcy w celu uzyskania zezwolenia na lokacje osad miejskich i towarzyszących temu przywilejów targowych, celnych i innych. Posiadali wreszcie wystarczajace środki materialne, wspomagające realizację lokacji. Obszarnikiem był zatem każdy rządca diecezji, czyli biskup, następnie przełożony klasztorny (opat, przeor, gwardian), a także świecki posiadacz majętności, właściciel kilkunastu, a nawet kilku wsi. Instytucje i ludzie uprzywilejowani, których poprzednicy i przodkowie lub oni sami zostali obdarzeni ziemią przez panującego monarchę, głównego niegdyś jej posiadacza.

Najnowsze badania nad uposażeniem kościoła potwierdzaja, że pochodzi ono $\mathrm{w}$ zasadniczym zrębie $\mathrm{z}$ XI stulecia, wskazując na panowanie w kraju króla Bolesława Śmiałego, który dokonał nadań na rzecz biskupstwa krakowskiego, przekazując mu wiele miejscowości podkrakowskich oraz kasztelanie majątkowe, m.in. kielecką ${ }^{10}$. Dopisać do nich należy kasztelanię sławkowska, prepozyturę wiślicką czy też enklawę iłżecką i tarczeńsko-bodzentyńką oraz dobra małopolskich zgromadzeń zakonnych, a więc benedyktynów, bożogrobców, cystersów, norbertanów, franciszkanów i dominikanów. Interesujące, że siedziby tych majętności sytuowano od XI w. bez wyjątku już w istniejących osadach grodowych, następnie (XII w.) grodowo-targowych, a nawet (XII-XIII w.) wsiach targowych. Odnosi się to w pełni do benedyktynów w Tyńcu, Sieciechowie i na Świętym Krzyżu, bożogrobców w Miechowie i Skaryszewie, cystersów w Jędrzejowie, Koprzywnicy, Wąchocku, Waśniowie i Wierzbicy, norbertanów w Brzesku i Busku, franciszkanów w Zawichoście, Skale i Sączu, dominikanów w Sandomierzu i Opatowcu. W każdej z tych miejscowości istniały zaczątki osad miejskich na prawie polskim, przekształcono je niebawem w miasta lokacyjne na prawie niemieckim w wersji średzkiej lub magdeburskiej.

${ }^{10}$ H. Łowmiański, Poczatki Polski, t. 6, cz. 1, Warszawa 1985, s. 84, 147, 365-370, $380 \mathrm{i}$ in. 
W tych miejscowościach dają się bowiem dostrzec najwcześniejsze udane lokacje miejskie.

Orientację o w miarę całościowym stanie własności kościelnej i szlacheckiej przynoszą dopiero dzieła Jana Długosza. Stanowia materiał ogromny, eksploatowany przez badaczy, lecz stosunkowo późny, odpowiadajacy stosunkom własnościowym dopiero z trzeciej ćwierci XV w., jednakże niepełny i niewolny od wielu opuszczeń i luk. Z pism tych dowiadujemy się, że dobra stołowe biskupa krakowskiego były skupione w XV w. w 16 kluczach majątkowych i obejmowały 251 wsi i 52 folwarki oraz 10 miast. Do skarbca biskupiego płynęły jeszcze dochody z dziesięcin ściaganych z 1257 wsi oraz 31 miast $^{11}$. Majętność rządcy diecezji krakowskiej poświadczaja następnie księgi dochodów z 1529 r., a przede wszystkim archiwalia skarbowe z trzeciej i czwartej części XVI w., na których podstawie przedstawił Adolf Pawiński przed 130 laty w swoich Źródta dziejowych ekonomiczny i społeczny obraz Polski XVI w. ${ }^{12}$ Nad tym, aktualnym do dzisiaj dziełem geograficzno-statystycznym, warto się nieco zatrzymać.

Na konkretnym materiale źródłowym przedstawił w nim bowiem zbliżony do rzeczywistości wizerunek kraju w okresie pomyślnym, określanym jako czasy złotego wieku. Przytoczył materiał konkretny, obejmujący całościowo ekonomikę i demografię królestwa, w tym i Małopolski, dostarczając podstawowych informacji o terytorium kraju, jego podziałach administracyjnych, a więc o obszarach prowincji (Małopolska, Wielkopolska), województw, powiatów, a nawet parafii, następnie o mieszkańcach żyjących w ówczesnych miastach i osadach wiejskich, a także o rozległości i zasięgu dóbr poszczególnych właścicieli włości. Jednakże, mimo niezaprzeczalnych walorów niepospolitego dzieła, Pawiński przedstawił statyczny obraz kraju, nakreślony nadto w realiach jego pomyślności, której nie można rozciagnąć na czasy wcześniejsze królestwa, niewolne od klęsk żywiołowych i wojennych ${ }^{13}$, kiedy istnienie wielu osad miejskich i wiejskich zostało gwałtownie

11 Z. Górczak, Podstawy gospodarcze działalności Zbigniewa Oleśnickiego biskupa krakowskiego, Kraków 1999, s. 33-39, 222-226.

${ }_{12}$ Źródta dziejowe, t. 14: Polska XVI wieku. Małopolska, t. 3, Warszawa 1886, s. $8-20$.

${ }_{13}$ Podamy tu przykładowo fakt wyjątkowo barbarzyńskiego, niszczaceego ziemie Małopolski południowo-wschodniej najazdu węgierskiego w 1474 r., kiedy ofiara padło 200 wsi i szereg miast (Jasło, Brzostek Kołaczyce, Dębowiec, Frysztak, Dukla, Pilzno); J. Dlugossii, Annales seu cronicae incliti regni Poloniae, lib. XII, Cracoviae 2005, k. 223-224; zob. też K. Baczkowski, Najazd węgierski na Podkarpacie w 1474 r., „Rocznik Województwa Rzeszowskiego” 9, 1978, s. 143-147. 
przerwane. Dotyczyło szczególnie miast szlacheckich, gdyż większe miasta królewskie i niektóre prywatne, przeważnie ufortyfikowane, zdołały się obronić. Nie wszystkie jednak. Niezaopatrzony w mury Opatów Wielki z kolegiata św. Marcina został unicestwiony, bohaterski opór obrońców z ludnością miejską w kościele Najświętszej Marii Panny na wzgórzu Opatowa Starego okazał się skuteczny i umożliwił przetrzymanie oblężenia ${ }^{14}$.

Na początku czwartej ćwierci XVI w. odnotował Pawiński w województwie krakowskim 71 miast (w tym 31 prywatnych) oraz w województwie sandomierskim 98 osad miejskich (w tym 74 prywatne). Co do województwa lubelskiego, napotkał na pustkowie źródłowe i podał wiadomości niepełne, wymieniając 8 miast w ziemi łukowskiej oraz $16 \mathrm{w}$ powiecie lubelskim i urzędowskim ${ }^{15}$. Mimo tego był to pierwszy, zbliżony do rzeczywistości, wykaz miast małopolskich; wielu historyków polskich zaczynało od tego rejestru, uświadamiał im bowiem kontury problemu, jaki zaważyli się rozpoznawać badawczo ${ }^{16}$.

${ }_{14}$ Zob. Opatów w XIII-XVI wieku. Materiaty z sesji 700-lecia miasta, red. F. Kiryk, Sandomierz 1985, s. 23-35 i przyp. 18, 19.

15 Źródta dziejowe..., t. 14, s. 150 i in.

${ }_{16}$ Adolf Pawiński podzielił własność gruntową na własność królewska, kościelną oraz szlachecką i scharakteryzował po raz pierwszy jej przynależność do instytucji i osób prywatnych, zauważając największe jej zgrupowanie w majątkach duchowieństwa diecezjalnego i zakonnego. Podał bowiem, że rządca diecezji krakowskiej posiadał aż 230 wsi i 4 miasta, natomiast kapituła krakowska miała na uposażeniu 46 wsi i 1 miasto; kapituły kolegiackie tej diecezji posiadały zdecydowanie mniejsze dobra: sandomierska - 8 wsi i 1 miasto, skalbmierska - 3 wsie i 1 miasto, opatowska - 1 wieś i tarnowska - 2 wsie. Do rozrzuconych w rozległej diecezji probostw dołaczył jeszcze 32 wsie. Były to majątki znaczne, zwłaszcza że nie uwzględnił dziesięcin, które przynosiły zwykle większe dochody niż dobra własne. Dla porównania tylko podamy, że arcybiskup gnieźnieński i prymas posiadał tylko 10 wsi i 1 miasto. Daje to możliwość stwierdzenia, że biskup krakowski był najbogatszym dostojnikiem kościelnym w Koronie. Pokaźne uposażenie gruntowe posiadały w tym czasie zgromadzenia zakonne: norbertanki w Busku - 6 wsi i 1 miasto, norbertanki w Nowym Brzesku - 5 wsi i 1 miasto, paulini częstochowscy - 7 wsi i 1 miasto, cystersi w Jędrzejowie 20 wsi i 1 miasto, cystersi w Koprzywnicy - 29 wsi i 1 miasto, cystersi w Wachocku - 14 wsi i 1 miasto, benedyktyni sieciechowscy - 21 wsi i 1 miasto, benedyktyni świętokrzyscy - 21 wsi i 2 miasta, bożogrobcy miechowscy - 42 wsie i 1 miasto, klaryski sądeckie - 48 wsi, kanonicy regularni w Mstowie - 5 wsi i 1 miasto; Źródła dziejowe..., t. 14, s. 72-73. Jednakże i te ustalenia okazały się niepełne, skoro pomijają posiadłości klasztoru tynieckiego, nie zauważając w zespole klarysek sądeckich miasta Starego Sącza, a w grupie cystersów wąchockich dwu osad miejskich, mianowicie Waśniowa i Wierzbicy, przydają z kolei klasztorowi łysogórskiemu dwa miasta, chociaż posiadał jedna tylko osadę miejską o nazwie Nowa Słupia; por. F. Kiryk, Urbanizacja Małopolski..., wg indeksu; tenże, Nowa Stupia miasto klasztoru świętokrzyskiego, „Studia Sandomierskie" 20, 2013, s. 129-179. 
Charakteryzując szlachecką własność ziemska, Pawiński stwierdził, że w Małopolsce (analogicznie jak w Wielkopolsce) przeważała własność jedno- lub kilkuwioskowej szlachty, zauważając, że „co wieś, to dwór szlachecki” oraz niemal obowiązkowo folwark. Nie brakowało tu jednak własności możnowładczej, oznaczającej fortuny magnackie w postaci 20-30 wsi, co oznacza, że każdy zespół dóbr magnackich obejmował 1/10 tego, co posiadał biskup krakowski. Tych możnowładczych majątków było w końcu XVI w. w Małopolsce kilkanaście. Przewyższała je na krótko tylko, zanim się nie rozpadła droga koligacji, fortuna ks. Konstantego Ostrogskiego, którego majętność obejmowała 80 wsi i kilka miast, lecz i ona była cztery razy mniejsza niż dobra stołowe biskupa krakowskiego ${ }^{17}$. Pawiński wymienił jeszcze majętności Jordanów (33 wsie), Zborowskich (30), Komorowskich (29), Szafrańców (22), Tarnowskich (z linii bocznej, 22), Stadnickich (21), Tarłów (19), Tęczyńskich (18), Ocieskich (17), Ciołków-Żelechowskich (17) oraz innych (Padniewskich, Niewiadomskich, Jordanów z linii bocznej, Brzezińskich, Sienieńskich, Mniszchów, Lanckorońskich, Koniecpolskich, Pieniążków, Mieleckich i Słupeckich).

Mimo uwag krytycznych co do kompletności majątków możnowładczych oraz szlacheckich (których nie opisał detalicznie), opracowanie Pawińskiego przybliżyło nauce rozmiary fortun kościelnych i możnowładczych oraz szlacheckich, zwracając uwagę również na odwrotna stronę zagadnienia, mianowicie na stan królewszczyzn, a w konsekwencji na słabość ekonomiczna królestwa. Na gruncie urbanizacji pozwoliło to na uzasadnienie faktu, iż w rozwoju miast prywatnych poważną rolę miastotwórczą odegrały instytucje (Kościół i klasztory) oraz reprezentanci możnowładztwa świeckiego, słabiej natomiast przedstawiają się $\mathrm{w}$ tej mierze reprezentanci szlachty.

$$
* * *
$$

Podejmując zagadnienie lokacji miast Małopolski, stwierdzić należy, że poświęcono mu wiele uwagi w opracowaniach syntetycznych i dziesiątkach monografii poszczególnych ośrodków miejskich. Przełomowy wpływ na poglądy historyków w tej mierze - pomijając opracowania dawne - wywarła powoływana już książka Karola Buczka o targach i miastach na prawie polskim. Udowodnił on, że były to miasta

17 Przypadłe Ostrogskiemu poprzez małżeństwo z Zofią, córką hetmana Jana Tarnowskiego oraz po zgonie jej brata Jana Krzysztofa Tarnowskiego; por. J. Leniek, F. Herzig, F. Leśniak, Dzieje miasta Tarnowa, Tarnów 1911, s. 90. 
początkowego etapu urbanizacji, nie miały wyodrębnionego terytorium, nie posiadały samorządu, miejskiego układu urbanizacyjnego, a jednak ich mieszkańcy odbiegali już od ludności chłopskiej zajęciami oraz poglądem na świat. Zainspirowani ustaleniami Buczka, kolejni historycy podjęli w kwestii początków miast dalsze badania, co znalazło wyraz przede wszystkim w publikacjach Benedykta Zientary ${ }^{18}$ oraz innych historyków ${ }^{19}$.

Z dociekań tych wynika, że przebieg lokacji miejskich nie był gwałtowny, lecz raczej długotrwały, gdyż przenikające do dzielnic Polski prawo niemieckie przyjmowało się tu etapami, nie stanowiąc jeszcze ukształtowanego systemu. Zabiegi lokacyjne zmierzały jednak do ustanowienia osady pod względem przestrzennym, jej zaludnienia i nadania jej kształtu ustrojowego w postaci - preferującego rozwój gospodarki towarowo-pieniężnej - prawa niemieckiego. Narodziny samorządu i uzyskanie autonomii, której wyrazem miała być gmina miejska rzadzona przez radę, następowały powoli i nie były równoznaczne z uzyskaniem przywileju lokacyjnego. Zachowało się ich zresztą niewiele ${ }^{20}$.

Ustalenia powyższe odnoszą się w pełni do najstarszych, lokowanych na prawie niemieckim w XIII i XIV w. miast prywatnych, czyli kościelnych i klasztornych ośrodków miejskich. Zapoznanie się z chronologią ich lokacji prowadzi do wniosku, że era tej właśnie grupy miast prywatnych nastała już w XIII stuleciu, kiedy prawa miejskie uzyskało 10 tego typu miejscowości (Nowe Brzesko, Brzeźnica, Jędrzejów, Miechów, Mstów, Skała, Skaryszew, Sławków, Stare Cło, Stary Sącz) w województwie krakowskim oraz 9 (Busko, Iłża Kielce, Koprzywnica, Kurzelów, Łagów, Opatowiec, Opatów, Tarczek) w sandomierskim. Interesujące jest to, że wszystkie były lokowane przy dawnych ośrodkach grodowych i targowych, a także portowych (Opatowiec) i górniczych (Sławków), będących również centrami religijnymi (klasztory, kolegiaty, parafie). Dodać do nich winniśmy jeszcze Pacanów, jedyną znaną nam

${ }^{18}$ K. Buczek, dz. cyt., s. 111-121; B. Zientara, Przemiany społeczno-gospodarcze i przestrzenne miast doby lokacji, w: Miasta doby feudalnej..., s. 66-97.

19 Por. T. Lalik, Geneza sieci miasteczek w Polsce średniowiecznej, w: Miasta doby feudalnej..., s. 113-136; A. Wyrobisz, Małe miasta w Polsce XVI i XVII w., w: tamże, s. 177-187; K. Modzelewski, Organizacja grodowa u progu epoki lokacji, KHKM, t. 28, 1980, nr 3, s. 329-340; H. Samsonowicz, Miasto i wieś na prawie niemieckim w późnym średniowieczu, PH, t. 63, 1972, s. 493-504; tenże, Przemiany osi drożnych w Polsce późnego średniowiecza, PH, t. 64, 1973, s. 697 n.

${ }^{20} \mathrm{~S}$. Kuraś, Przywileje prawa niemieckiego miast $i$ wsi małopolskich XIV-XV wieku, Wrocław 1971, s. 77-113; B. Zientara, dz. cyt., s. 66-90; tenże, Organizacja rynku w średniowieczu, PH, t. 64, 1973, s. 693 n.; M. Bogucka, H. Samsonowicz, dz. cyt., s. $40-88$. 
w Małopolsce miejscowość szlachecka, która w XIII w. (1265) otrzymała prawa miejskie. W XIV w. do owych miast klasztornych i kościelnych doszło jeszcze 15 osad miejskich, co czyniło 38 miast duchownych, czyli blisko 1/3 wszystkich ówczesnych (140) miast małopolskich.

Wieki kolejne nie zaowocowały już w miasta duchowne, skoro w XV stuleciu usiłowano powiększyć ich stan o 12 założeń miejskich, a w stuleciu kolejnym jeszcze o 3 lokacje, ale próby powołania ich do życia okazały się przeważnie nieudane. Trwały i owocny udział czynników kościelnych i klasztornych w urbanizacji Małopolski kończył się praktycznie - tak jak miast monarszych, których lokowano w XIII i XIV w. 80 (a w XV i XVI stuleciu zaledwie 6) - na okresie przedjagiellońskim. Wynika z tego jeszcze, że wieki XV i XVI stanowia w dziejach urbanizacji Małopolski epokę przede wszystkim prywatnych miast szlacheckich.

Dodamy tu jeszcze, że uwagę zwraca skuteczność lokacji miast monarszych i duchownych. Wskazuje to na zapewnione wsparcie materialne i przestrzenne ich lokacji ze strony właścicieli włości, na których obszarze powstawały. Wyrażało się ono (nie bagatelizując takich czynników jak położenie wobec szlaków komunikacyjnych terenowych i wodnych, lokalnych zasobów naturalnych, centrów administracji państwowej i kultu religijnego czy zaludnienia otaczających je osad wiejskich itp.) najjaskrawiej $\mathrm{w}$ fakcie lokacji tych miast przy grodach i zamkach książęcych i królewskich, głównie tych, na których gruncie wyrosły wcześniej podgrodzia i osady targowe, czyli ośrodkach wymiany towarowej określanych jako miasta na tzw. prawie polskim. Zrozumiały staje się na tym tle fakt, że w uposażeniu biskupstwa krakowskiego i klasztorów znalazły się od początku w Polsce atrakcyjne pod względem osadniczym obszary diecezji krakowskiej, w tym Wiślica, Sandomierz, Skalbmierz, Sławków, Tyniec, Koprzywnica czy Zawichost oraz okolice Kielc i Tarczku, a także Iłży, Radomia i Sieciechowa. Nie można nie dostrzec, że powodzenie lokacji miasta zależało od inicjatywy właściciela i gotowości świadczenia przezeń pomocy w zakresie pozyskania przestrzeni miejskiej, jej zabudowy i sprowadzania dla osadzenia w niej przyszłych mieszkańców. Jednakże nawet gdy się to układało, lokacja miasta nie przestawała być procesem długotrwałym i inwestycją niesłychanie kosztowna.

Sumujac dotychczasowe rozważania, stwierdzamy, że do końca epoki piastowskiej powstawały w Małopolsce główne ośrodki miejskie należące do domeny królewskiej oraz włości kościelnych i klasztornych. Wyznaczały one kierunek i stopień urbanizacji królestwa, której apogeum dostrzegamy w okresie monarchii Kazimierza Wielkiego. Później 
niemal wszystko, co w urbanizacji Małopolski się zdarzyło, dotyczyło słabiej zagospodarowanych i rzadziej zabudowanych obszarów Sandomierszczyzny oraz województwa lubelskiego, objętych w XV, a szczególnie w XVI w., żywiołowym i niekontrolowanym nurtem lokacji miast magnacko-szlacheckich. Nie powstawały później niemal miasta monarsze, nie pojawiały się długo także rachityczne duchowne ośrodki miejskie. Nastapił inny czas, inne warunki, wystapiły inne siły napędowe.

Dorobek osadniczy minionej epoki był jednak ogromny, skoro na obszarze Małopolski powołano do życia 140 osad miejskich na prawie niemieckim, z których co najmniej 100 prezentowało potencjał gospodarczy i społeczny, aby wypełniać zapotrzebowanie kraju na ośrodki administracji państwowej i kościelnej, a przede wszystkim na regionalne i lokalne centra produkcji oraz wymiany towarowej. Odnosi się to w pełni do Małopolski południowo-wschodniej, objętej granicami województwa krakowskiego, gdzie nasycenie ośrodkami miejskimi zostało osiagnięte już w schyłkowej fazie rządów ostatniego Piasta na tronie polskim. Było wysokie tak dalece, że przyrost nowych miast nie był już potrzebny, został na dłuższy czas skutecznie zahamowany.

Istotnie, urbanizacja kraju (nie tylko Małopolski) potoczyła się w czasach andegaweńskich i jagiellońskich innymi torami. Złożyło się na to wiele czynników, w tym zwłaszcza zmiany geopolityczne wynikające z włączenia Rusi Czerwonej do Królestwa Polskiego i przede wszystkim zawarcia unii polsko-litewskiej, a także zbliżania się gospodarki polskiej do strefy bałtyckiej. Łączy się z tym również nieumiarkowany rozwój królewskich zastawów i nadań ziemskich na rzecz ludzi zasłużonych wobec dynastii, co łatwo dostrzec podczas długiego panowania króla Jagiełły, a zwłaszcza krótkich rządów jego następcy, Władysława Warneńczyka.

Starając się ujaćc postępy urbanizacji tabelarycznie, naliczyliśmy istnienie w XIII-XVI w. w trzech województwach małopolskich, w rozbiciu na poszczególne wieki, 252 miasta lokowane na prawie niemieckim. Udało się ustalić jednak, że na wymienionym terytorium usiłowano przeprowadzić 267 lokacji miejskich, lecz w stosunku do kilkunastu z nich zabiegów takich nie podjęto lub je przerwano i zaniechano. W rezultacie, na obejmującym $19635 \mathrm{~km}^{2}$ obszarze województwa krakowskiego powołano do końca XVI w. 88 ośrodków miejskich, województwa sandomierskiego $\left(25726 \mathrm{~km}^{2}\right)$ założono 123 miasta oraz województwa lubelskiego $\left(11033 \mathrm{~km}^{2}\right)$ - 41 osad miejskich, w tym miast królewskich 75, miast duchownych 53, magnackich i szlacheckich 124 $(\text { razem } 252)^{21}$. Zamieszczona na końcu artykułu tabela przedstawia

\footnotetext{
${ }^{21}$ Por. Źródta dziejowe..., t. 14, s. 8-20, zob. też tab.
} 
stan miast istniejacych w XIII-XVI stuleciu, lokowanych przez właścicieli ziemskich oraz nadanych przez monarchów instytucjom kościelnym, a także osobom prywatnym. Wśród tych miast znalazło się $\mathrm{w}$ ten sposób w dobrach biskupstwa krakowskiego w 1391 r. miasto Muszyna z zamkiem, a w 1443 r. droga zakupu Siewierz i Czeladź, nieco później Koziegłowy, w 1434 r. natomiast - jako akt królewskiej hojności na rzecz biskupa przemyskiego - miasto Jaśliska. Wspomnimy tu jeszcze o nadaniu przedstawicielom rodu Zadorów przez Kazimierza Wielkiego zamku z miastem Wodzisławiem, które stało się niebawem siedziba rodową Lanckorońskich z Brzezia, a wreszcie o nadaniach królewszczyzn w końcu XIV w. na rzecz Włodka z Charbinowic, starosty lubelskiego (1386), zamku i miasta Ogrodzieńca oraz sasiedniego miasta Włodowic, a także Secemina w 1395 r. za zasługi Piotrowi Szafrańcowi ${ }^{22}$.

$* * *$

Obraz małopolskich miast prywatnych był pod każdym względem niejednolity i zróżnicowany. Próby zestawienia ich pod względem funkcji, przy znacznych defektach źródłowych, mogą być tylko niepełne i podane orientacyjnie. Z drugiej strony nie brak wśród nich ośrodków produkcyjnych górniczych i hutniczych oraz rzemieślniczych, a także o charakterze usługowym i konsumpcyjnym (handlowych i administracyjnych, rezydencjonalnych i obronnych, a także oświatowych i religijnych). Przeważały jednak zdecydowanie miasta małe, odpowiadające w świetle ustawy z 1520 r. przeważnie trzeciej kategorii miast, grupującej civitates et oppida habentia fora annualia et septimanalia, czyli rzemieślniczo-handlowe ośrodki miejskie, ale o znacznym udziale gałęzi rolniczo-hodowlanej. Wszystkie niemal łączyły funkcje produkcyjne i handlowe z usługowymi, administracyjnymi i religijno-oświatowymi, a sporo także $\mathrm{z}$ rezydencjonalnymi i obronnymi.

$\mathrm{Na}$ początek wysuwają się tu miasta, na których gruncie rozwijało się górnictwo i przemysł hutniczy. Przodował tu zdecydowanie Sławków wydobyciem rud ołowianych i miejscowa produkcja hutnicza, a także Chrzanów, Nowa Góra i wcześnie zurbanizowana osada wiejska pod nazwą Trzebinia. Równocześnie rozwijał się przemysł wydobywczy i hutniczy. Z 1322 r. zachowała się wiadomość o kuźnicach o napędzie

${ }^{22}$ ZDM, t. 6, wyd. I. Sułkowska-Kuraś, S. Kuraś, Wrocław 1975, nr 521; Matricularum Regni Poloniae summaria, t. 4, wyd. T. Wierzbowski, Varsoviae 1917, supl., nr 320; SPPP, t. 2, wyd. A.Z. Helcel, [Kraków] 1870, nr 3750; AGZ, t. 5, Lwów 1875, nr 21, por. nr. 22, 26, 35; S. Gawęda, dz. cyt., s. 49, 72. 
wodnym w rejonie Szczekocin, z 1383 r. o budowie kuźnicy żelaznej (ferrifabrica) o 3 kołach w sąsiedztwie Iłży, z końca tego wieku pochodzi informacja o kuźnicy we wsi Sądek k. Opoczna, włości klasztoru cystersów jędrzejowskich. Ustalono wreszcie, że w XVI stuleciu pracowało na obszarze lewobrzeżnej Sandomierszczyzny ponad 60 kuźnic żelaznych, poruszanych przez 162 koła wodne, co nie oznacza jednak, że dostępne nam dzisiaj źródła odnotowały wszystkie ówczesne zakłady kuźnicze. Trudno nie zauważyć, że górnictwo i hutnictwo stanowiło już w XIII i XIV w. dźwignię postępu technicznego na ziemiach polskich, gdyż kuźnice wytwarzały nie tylko surowiec, lecz także narzędzia pracy dla rolnictwa (pługi, siekiery, topory, łańcuchy, sierpy, kosy), dostarczały wyrobów kuźniczych do kopalń, w tym do żup solnych w Bochni i Wieliczce, z XVI w. zachowały się źródła świadczące, że kuźnice cystersów wąchockich produkowały broń dla króla i armii. Surowiec żelazny wywożono do Mołdawii, na Litwę i do Moskwy ${ }^{23}$.

Górnictwo i hutnictwo koncentrowało się w rejonie Gór Świętokrzyskich, przeważnie w okolicy Iłży, Bodzentyna, Nowej Słupi, Jastrzębia, Kielc i Wachocka, gdzie pracowały nie tylko kuźnice żelazne, lecz także huty szkła. Przodowały tu zdecydowanie okolice Iłży, Bodzentyna i Wąchocka, tyle że ośrodek produkcji przedmiotów żelaznych zlokalizowany był w pobliskim Kunowie, mieście wytwórców narzędzi, blach, wszelakich okuć i gwoździ oraz artykułów ślusarskich. W Łagowie natomiast powstało, poza kuźnicami i hutnictwem szkła, centrum produkcji ceramicznej opartej na wydobyciu specjalnej glinki garncarskiej. Trudna do określenia rolę odegrały źródła solne w Busku i Tuchowie, a także wydobycie rud miedzianych w okolicach Chęcin. Wszędzie jednak przemysł wydobywczy i hutniczy ożywiał handel artykułami metalowymi i ceramicznymi, nie tylko w Łagowie i Iłży, lecz także w Wąchocku i Szydłowcu, gdzie powstawały konfraternie kupieckie, a także w Ćmielowie, gdzie zarejestrowano w 1578 r. blisko sto warsztatów rzemieślniczych, oraz w Koprzywnicy, gdzie w 1578 r. wykazano 125 rękodzielników.

W produkcji i handlu tekstyliami wybijały się miasta Podkarpacia, zwłaszcza Bobowa, Gorlice, Dukla, Żmigród, Frysztak, a także Czudec i Strzyżów, w którym wykazano w trzeciej ćwierci XVI w. 67 mieszczan bez roli, utrzymujaccych się z produkcji płótna, sukna i przędzy, wysyłanych przeważnie na rynki miast północnych Węgier. W wymienionych powyżej miast karpackich odnotowano urządzenia blecharskie i folusznicze, a w nadgranicznym Żmigrodzie nawet wodociagi i kanały.

${ }_{23}$ B. Zientara, Dzieje małopolskiego hutnictwa żelaznego XIV-XVII wieku, Warszawa 1954, s. 90-95, 152, 153, 157, 158. 
Ośrodkami produkcji rzemieślniczej i wymiany towarowej były jednak miasta większe, według wspomnianego przed chwila podziału z 1520 r. - drugiej kategorii, do których wypadnie zaliczyć Opatów i Tarnów. Za nimi podazżały miasta mniejsze, lecz dochodzące do tysiąca mieszkańców, a więc Pińczów, Szydłowiec, Ćmielów, Iłża, Kielce, Pacanów, Koprzywnica, Busko, Bodzentyn, Kunów, a także Opatowiec, Iwaniska, Staszów, Secemin, Skrzynno, Lewartów. Pozycje lokalnego centrum handlowego $\mathrm{w}$ miastach prywatnych zdradzaja wiadomości o funkcjonowaniu ratuszów jako punktów produkcyjnych i handlowych (postrzygalnia, waga, piwiarnia), otoczonych placem targowym, co możemy dostrzec na przykładzie Bobowej, Bodzentyna, Pilicy, Pińczowa, Żmigrodu i zapewne wielu innych prywatnych miast małopolskich, a także informacje o miastach zbożowych, poświadczających istnienie rynków na płody rolne, jak też hodowlane. Sa to informacje ważne i dotąd skromnie wykorzystane przez badaczy dziejów miast. Udało się je wydobyć ze źródeł w odniesieniu do przynajmniej 20 małopolskich miast prywatnych (Bobowa, Bodzentyn, Chrzanów, Dębica, Frysztak, Jędrzejów, Koziegłowy, Miechów, Opatowiec, Pilica, Siewierz, Skalbmierz, Skała, Skawina, Tarnów, Tuchów, Wielopole Skrzyńskie, Żmigród) i zapewne szeregu innych, jak Iłża, Kielce, Myślenice, Nowy Targ, Opatów, Oświęcim, Skrzynno, Zawichost ${ }^{24}$.

Większość opisywanych tu miast prywatnych spełniała rolę ośrodków oświatowych. Stanowiły bowiem osady parafialne, niektóre nawet prepozyturalne, wszystkie ze szkołami, gdyż w XV i XVI w. nie brakowało ich w jakiejkolwiek parafii. Pouczający jest wykaz ich absolwentów, którzy ukończyli studia na Akademii Krakowskiej z tytułem bakałarza. Wielu ich wywodziło się z Jędrzejowa, Koprzywnicy, Kromołowa, Miechowa, Mstowa, Pilicy, szczególnie wielu z Iłży, Ksiaża, Opatowa, Sącza i Tarnowa ${ }^{25}$. Dochodzą do tego liczne szkoły różnowiercze, jako że możnowładcze i szlacheckie miasta prywatne stały się już w połowie XVI w. oparciem dla reformacji kalwińskiej i ariańskiej. Korzenie różnowierstwa usiłowali zapuścić w swoich miastach przede wszystkim ich magnaccy i szlacheccy właściciele. Tylko w województwie sandomierskim istniały zbory różnowiercze w 30 miastach, których część mieszkańców (Raków, Pińczów, Secemin, Staszów) przyjęła nową wiarę. Nie odbywało się to wszystko dobrowolnie. Zerwanie ze

${ }^{24}$ Księga dochodów beneficjów diecezji krakowskiej z roku 1529 (tzw. Liber retaxationum), wyd. Z. Leszczyńska-Skrętowa, Wocław 1968, s. 661.

${ }_{25}$ Zob. Ksiega promocji Wydziału Sztuk Uniwersytetu Krakowskiego z XV wieku, wyd. A. Gąsiorowski, współpr. T. Jurek, I. Skierska, Kraków 2000, wg indeksu. 
stara religia miało $\mathrm{w}$ wielu miejscowościach przebieg dramatyczny, że wymienimy tylko Książ, Pińczów, Oleśnicę, Sienno i Żabno. Mniejsze zainteresowanie nowinkami religijnymi miało miejsce $\mathrm{w}$ osadach miejskich województwa krakowskiego, gdzie zaszczepieniem reformacji wyróżniały się Książ, Kossów, Kromołów, Ogrodzieniec, Wodzisław i Żarki, w województwie lubelskim natomiast Kock, Lewartów i Piaski. Rezydencjonalne funkcje spełniały miasta posiadające zamki, pałace i dwory pańskie, łącząc je zwykle, chociaż nie zawsze, z funkcja produkcyjną ${ }^{26}$, a więc w Bodzentynie, Ćmielowie, Janowcu, Kielcach, Koprzywnicy, Kurozwękach, Mielcu, Rzemieniu, Sobkowie, Szydłowcu, Tarnowie, Włoszczowie ${ }^{27} \mathrm{i}$ innych.

Tabela 1. Lokacje miast prywatnych w Małopolsce w XIII-XVI w.

\begin{tabular}{|c|c|c|c|c|c|c|c|c|c|c|c|c|c|c|c|c|}
\hline \multirow[t]{2}{*}{ Własność } & \multicolumn{5}{|c|}{$\begin{array}{l}\text { Województwo } \\
\text { krakowskie }\end{array}$} & \multicolumn{5}{|c|}{$\begin{array}{l}\text { Województwo } \\
\text { sandomierskie }\end{array}$} & \multicolumn{5}{|c|}{$\begin{array}{l}\text { Województwo } \\
\text { lubelskie }\end{array}$} & \multirow[b]{2}{*}{$\begin{array}{l}\cdot \mathscr{D} \\
\Xi \\
\Xi \\
B \\
B\end{array}$} \\
\hline & $\stackrel{\dot{3}}{\dot{B}}$ & $\begin{array}{l}\dot{3} \\
\vec{x}\end{array}$ & $\dot{\vec{x}}^{\dot{x}}$ & $\underset{x}{3}$ & $\begin{array}{l}\text { घี } \\
\text { एँ. } \\
.0 \\
0\end{array}$ & $\stackrel{\dot{3}}{\vec{\Xi}}$ & $\dot{z}_{\vec{x}}^{\dot{3}}$ & $\vec{x}_{x}^{\dot{3}}$ & $\underset{x}{\overrightarrow{3}}$ & 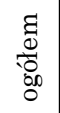 & $\stackrel{3}{\vec{B}}$ & $\vec{x}_{\vec{x}}^{\dot{3}}$ & $\stackrel{\overrightarrow{3}}{\vec{x}}$ & $\frac{\dot{3}}{\vec{x}}$ & $\begin{array}{l}\text { घ्ञ } \\
\stackrel{0}{0} \\
80 \\
0\end{array}$ & \\
\hline królewska & 10 & 34 & 1 & - & 45 & 7 & 12 & 1 & 1 & 21 & 0 & 4 & 3 & 1 & 8 & 75 \\
\hline kościelna & 13 & 4 & 1 & - & 18 & 10 & 11 & 9 & 2 & 32 & - & - & 2 & 1 & 3 & 53 \\
\hline szlachecka & - & 17 & 4 & 4 & 25 & 1 & 13 & 20 & 36 & 70 & - & 2 & 8 & 20 & 30 & 124 \\
\hline Razem & 23 & 55 & 6 & 4 & 88 & 18 & 36 & 30 & 39 & 123 & 0 & 6 & 13 & 22 & 41 & 252 \\
\hline
\end{tabular}

Źródło: F. Kiryk, Rozwój urbanizacji Małopolski XIII-XVI w., Kraków 1974, mps rozprawy habilitacyjnej, Archiwum Uniwersytetu Pedagogicznego w Krakowie.

\section{Bibliografia}

Bogucka M., Samsonowicz H., Dzieje miast i mieszczaństwa $w$ Polsce przedrozbiorowej, Wrocław 1986.

Buczek K., Targi i miasta na prawie polskim, Wrocław 1964.

Gawęda S., Możnowtadztwo małopolskie w XIV i pierwszej połowie XV wieku, Kraków 1966.

Górczak Z., Podstawy gospodarcze działalności Zbigniewa Oleśnickiego biskupa krakowskiego, Kraków 1999.

Kiryk F., Miasta ziemi sqdeckiej w XIII-XVI wieku, „Rocznik Sądecki” 35, 2007, s. 25-116.

${ }^{26}$ F. Kiryk, Urbanizacja Małopolski..., passim.

${ }^{27}$ Kończąc niniejsze ujęcie, winniśmy jeszcze podać, że zostało one przedstawione 19 X 2015 r. na posiedzeniu naukowym Wydziału II Polskiej Akademii Umiejętności, stając się podstawą do żywej dyskusji oraz zachęty, aby tematyce miast prywatnych w Małopolsce poświęcić gruntowne opracowanie książkowe. 
Kiryk F., Rozwój urbanizacji Małopolski XIII-XVI w. Województwo krakowskie (powiaty potudniowe), Kraków 1985.

Kiryk F., Urbanizacja Małopolski. Województwo sandomierskie XIII-XVI wiek, Kielce 1994.

Kiryk F., $Z$ badań nad urbanizacja Lubelszczyzny w dobie jagiellońskiej, „Rocznik Naukowo-Dydaktyczny WSP w Krakowie” 43, 1972, s. 93-167.

Miasta doby feudalnej w Europie Środkowo-Wschodniej. Przemiany społeczne a uktady przestrzenne, red. A. Gieysztor, T. Rosłanowski, Warszawa 1976.

Motylewicz J., Miasta ziemi przemyskiej i sanockiej $w$ drugiej połowie XVII i XVIII w., Przemyśl 1993.

Sieć miejska na ziemiach polskich w XIII-XVII w., KHKM, t. 28, 1980, nr 3.

Feliks Kiryk

Private towns of Lesser Poland in the $13^{\text {th }}-16^{\text {th }}$ century (Summary)

Even though private towns constituted $2 / 3$ of all urban centres founded in Lesser Poland in the $13^{\text {th }}-16^{\text {th }}$ century, they have not yet been properly researched, mostly due to the scarcity of source materials. The author carries out a comprehensive analysis of the chronology of town foundation in Lesser Poland and presented statistics concerning towns in a table. He concludes that main urban centres, belonging to the king and the Church, were founded in Lesser Poland until the end of the Piast era. The urbanisation in the region was at its most dynamic during the reign of Casimir the Great. Later on, towns were founded mostly in less developed and built-up areas of Sandomierszczyzna and Lubelskie Voivodeship, which in the $15^{\text {th }}$ and, most prominently, in the $16^{\text {th }}$ century experienced an uncontrolled wave of foundations of magnate and noble towns, with almost total disappearance of royal foundations. Private towns had diverse economic functions. Most of them also served as educational centres.

Feliks Kiryk - (ur. 1933), mediewista, historyk miast, regionalista i wydawca źródeł, emerytowany profesor Uniwersytetu Pedagogicznego w Krakowie, członek-korespondent Polskiej Akademii Umiejętności, doktor honoris causa Uniwersytetu Lwowskiego (1998) i Rzeszowskiego (2007), profesor honorowy Uniwersytetu Pedagogicznego w Kamieńcu Podolskim (2001), były wiceprezes Zarządu Głównego Polskiego Towarzystwa Historycznego. Autor ponad 500 prac naukowych, inicjator, redaktor i współautor kilkudziesięciu monografii miast Małopolski i innych regionów historycznych (m.in. Kamieńca Podolskiego). Jego pionierskie badania nad urbanizacją Małopolski otworzyły nowy rozdział w historiografii polskiej. 